\title{
Effectiveness of Non-Pharmacologic Strategies for Parental Smoking Cessation to Protect Children: A Meta-Analytic Review
}

\author{
Stefanie Nichole Tan, $R N, M D^{1}$; Jose $H$. Caduhada, $M D^{\prime}$; \\ Ma Teresa Tricia G. Bautista, MD'
}

\section{ABSTRACT}

Aims: This meta-analysis aims to synthesize available evidence from published studies on the effectiveness of parental non-pharmacologic smoking cessation programs which aim to reduce children's exposure to secondhand smoke.

Methodology: A database search using The Cochrane Library, PubMed $\circledast$, Medline, Embase, and Google Scholar, was done by the investigators. This study included 20 randomized controlled trials published up to 2020 . Pooled estimates of risk ratio (RR) for quit rates were computed using the random effects model.

Results: Overall, the quit rate among those who underwent parental smoking cessation was $13.4 \%$ while the quit rate for controls was $11.9 \%$. The pooled RR demonstrated that the parental smoking cessation program was significantly associated with higher quit rates $(R R=1.22,95 \% \mathrm{Cl}=1.01$ to 1.46 , p-value $=0.04)$. The studies demonstrated moderate heterogeneity only $\left(\mathrm{I}^{2}=54 \%\right)$. Among studies published prior to year 2000, no significant difference was observed between parental smoking cessation program and control $(R R=1.02,95 \%$ $\mathrm{Cl}=0.62$ to $1.70, p$-value $=0.93)$. On the other hand, the pooled RR demonstrated that among

Jose H. Caduhada

joecaduds@gmail.com

1. Department of Family Medicine, University of Santo Tomas Hospital studies published after 2020, parental smoking cessation program was significantly associated with higher quit rates $(R R=1.27,95 \% \mathrm{Cl}=1.03$ to 1.56, p-value <0.0001). Among studies with self-help interventions, parental smoking cessation program has no additional benefit on quit rates ( $R R=1.20,95 \% \mathrm{Cl}=0.94$ to 1.58 , $p$-value $=0.14$ ). Among studies with biofeedback intervention also, no significant difference was observed $(R R=1.27$, $95 \% \mathrm{Cl}=0.86$ to 1.89 , $p$-value $=0.23$ ).

Conclusions: This meta-analysis demonstrated sufficient evidence that non-pharmacologic interventions for parental smoking cessation are effective.

Key words: smoking cessation, second-hand smoke, family interventions, non-pharmacologic, meta-analysis

\section{INTRODUCTION}

In a report by the World Health Organization (WHO), smoking kills 8 million people a year. [1] Efforts to prevent smoking-related morbidity and premature mortality depends on prevention programs, policies protecting people from secondhand smoke exposure, and effective smoking cessation programs. Regardless of their age or how long they have been smoking, one of the most important actions people can take to improve their health is to quit smoking. Smoking cessation has 
proved to improve one's cardiovascular, respiratory, and reproductive health.[2] Moreover, quitting smoking prevents tobacco exposure to non-smokers. In non-smokers, carbon monoxide levels in the blood decrease after several days after the time of quitting. [2] However, quitting smoking is very challenging, with most of the quitters relapsing over time. The causes may vary but the most common are due to stress, weight gain, and symptoms of nicotine and tobacco withdrawal.[3] Despite this, the progress in global tobacco control is still struggling. Creating an environment that facilitates smoking cessation is important such as providing counselling in primary care settings and operating national toll-free quit telephone lines.[4]

A meta-analysis concluded that increased risk perceptions should be included in health behaviorspecific theories since there was an association found with healthier behaviors and increased risk perception.[5] This may also be applied in smoking cessation intervention programs. Another important theoretical concept to consider is social support, as this may be helpful in understanding smoking cessation in families.[6] However, there should be a coherent rationale for adopting a family-based approach to aid cessation in families. Concepts such as these may be particularly helpful when a smoker considers the health of his/her own family, such as the benefits it brings to children: reduced risk of cardiovascular diseases, lung cancer, and lower risk of sudden infant death syndrome (SIDS).[2]

Various studies have shown a parent's concern for his/her child's health is a strong motivation for quitting smoking. Different tools to aid in smoking cessation have been utilized, such as cognitivebehavioral approaches, self-help materials, counseling, and biofeedback.[7] A 2012 metaanalysis with 18 trials has shown that smoking cessation interventions tailored to parents who smoke are modestly effective.[8] Further research on how these interventions can be improved would help increase its effectiveness, such as by including tobacco prevention intervention aimed at children. [9] By promoting cessation in smokers and preventing tobacco initiation in children, secondhand smoke exposure also decreases and provides better health outcomes for both smokers and non-smokers.

Various interventions have proven to be effective in limiting children's secondhand smoke exposure at home. However, its efficacy is limited compared to interventions aimed at parental smoking cessation. Studies have shown that parental smoking behavior has an influence on children's smoking behavior and is related to the persistence of children smoking.[10] This may be due to the accessibility of cigarettes to children, which increases their risk to smoke and usually persists long term. [1 1] Exposing children to tobacco smoke in their own homes from their parents is a risk factor in smoking initiation. In addition, parents who smoke not only harm their health, but also the health of their children, as they increase the risk of secondhand smoke exposure.[12] Respiratory diseases caused by secondhand smoke exposure have resulted in 15,000 children being hospitalized annually. [9] Therefore, it is important to promote smoking cessation in parents who are smokers as early as possible because this would lead to the prevention of tobacco initiation in children.

In this paper, we present meta-analyses of parental quit rates from trials that focused on protecting children from tobacco smoke exposure through parental cessation or modification of parental smoking patterns. The cessation among smoking parents of children was evaluated.

The aim of this study is to synthesize available evidence from published studies on the effectiveness of parental non-pharmacologic smoking cessation programs, which aim to reduce children's exposure to secondhand smoke. Other goals are to compare the parental quit rates between those who underwent smoking cessation programs versus those who did not and to determine which intervention components of parental smoking cessation programs have the most benefit.

\section{METHODOLOGY}

A literature search from various search engines and electronic databases such as The Cochrane Library, PubMed®, Medline, Embase, and Google Scholar was done by the investigators. The search strategy: (smoking OR cigarette OR tobacco) AND (cessation OR control) AND (parental OR mother OR father OR maternal OR paternal) AND (children OR pediatric OR child OR infant) was used. The Medical Subject Headings (MeSH) was employed when searching a database where available. Backward searching of references cited in included studies was also done. Articles were reviewed and selected according to the set inclusion criteria. 
Studies included are those smoking cessation interventions done among cigarette-smoking parents (father, mother or both aged 18 years and above) of pediatric age (ages of 0 to 18 years) in one of the following cohorts: well children (visiting well-child clinics and population cohorts), asthmatic children, or pediatric clinics or hospitals. Randomized control trials were included which compared the effectiveness of parental smoking cessation programs versus no intervention. The search was limited to studies written in English. Only original studies were included. Other forms of publications such as observational studies, case reports or series, reviews, letters, and editorials were excluded.

Full-text copies of studies to be included were saved in an online Google drive accessible to the investigators. The risk of bias scorings and extracted data from the studies were managed using the Review Manager (RevMan) 5.4 software. Two authors independently evaluated the abstracts generated by the search strategy for inclusion. Those that meet the inclusion criteria were retrieved as fulltext versions. The full-text articles were then reviewed again based on the inclusion and exclusion criteria. The two authors then compared their list of included studies. Any discrepancies were compared and disagreements were resolved through discussion between the two authors. Two investigators independently extracted data from the full-text articles. The information needed includes the study design, description of smoking cessation program, patient outcomes studied, characteristics of the study population, setting, number of participants, method for patient selection, method of randomization and concealment of treatment allocation, patient dropouts, length of observation, program provider, and intent of treatment. After data collection, the two investigators then compared their list of included studies. Any discrepancies were compared and disagreements resolved through discussion with the other review author.

The Cochrane Collaboration Risk of Bias Tool was used to assess the methodological quality of studies included in the meta-analysis. All the included randomized trials were evaluated based on the following: randomization, blinding, concealment of allocation, treatment of incomplete outcome data, selective reporting, and other biases. A rating of 'low risk of bias,' 'high risk of bias' or 'unclear risk of bias' was scored for each category. Two investigators independently assessed each study. Discrepancies were compared and discussed until a consensus among the investigators was reached.

The pooled estimate of RR to represent quit rates was computed along with $95 \%$ confidence intervals $(\mathrm{Cls})$. The point estimate of the RR was deemed significant if the p-value is $<0.05$. The Mantel-Haenszel fixed-effects model was used if heterogeneity was not high, otherwise the randomeffects model was used. $\left.\right|^{2}$ statistics were used to assess heterogeneity (significant if $>60 \%$ ) and funnel plots used to assess the possibility of publication bias. Sub-group analyses were also conducted to explore heterogeneity. The authors used RevMan 5.4 for statistical analysis.

\section{RESULTS}

The literature search resulted in a total of 1,936 non-duplicate articles for screening. After abstract screening, 32 articles were retrieved for full text review. Seven studies were further excluded because they were not comparative studies or involved pharmacologic interventions. Five articles were excluded since they did not report parental quit rates. A total of 20 studies were finally included in the meta-analysis. The study characteristics are summarized in Table 1.

Overall, the studies were of good quality and showed low risk for bias. None of the studies had blinding among participants and providers of intervention because there was no feasible method for blinding in this kind of study. In this kind of study, it is unlikely however that bias may arise when participants or personnel were aware of the intervention groups. About $30 \%$ of studies did not describe the method for allocation concealment and blinding of staff who assessed patient outcomes. None of the studies had high drop-out rates and none had selective outcome reporting. The details of risk of bias assessment can be seen in Figure 2 .

Four studies have shown significantly higher quit rates among those who underwent parental cessation programs and the rest of the 16 studies showed no significant difference. Overall, the quit rate among those who underwent parental smoking cessation was $13.4 \%$ while the quit rate for controls was $11.9 \%$. The pooled RR demonstrated that the parental smoking cessation program was significantly associated with higher quit rates 
Table 1. Characteristics of included studies

\begin{tabular}{|c|c|c|c|c|c|c|c|c|c|}
\hline Study & $\begin{array}{c}\text { Age of } \\
\text { Child at } \\
\text { Recruitment }\end{array}$ & $\begin{array}{l}\text { Child } \\
\text { Cohort }\end{array}$ & Setting & Provider & $\begin{array}{l}\text { No. of } \\
\text { Sessions }\end{array}$ & $\begin{array}{l}\text { Theory } \\
\text { Based }\end{array}$ & $\begin{array}{l}\text { Length of } \\
\text { Observation }\end{array}$ & $\begin{array}{l}\text { Primary } \\
\text { Goal }\end{array}$ & $\begin{array}{l}\text { Intervention } \\
\text { Components }\end{array}$ \\
\hline
\end{tabular}

\begin{tabular}{|c|c|c|c|c|c|c|c|c|c|}
\hline $\begin{array}{l}\text { Abdul- } \\
\text { lah et al } \\
(2005) \\
{[13]}\end{array}$ & 5 years & Well & $\begin{array}{l}\text { Well-baby } \\
\text { clinic }\end{array}$ & $\begin{array}{l}\text { Research } \\
\text { assistant }\end{array}$ & 3 & Yes & 6 months & Cessation & $A, C$ \\
\hline $\begin{array}{l}\text { Abdul- } \\
\text { lah et al } \\
(2015) \\
{[14]}\end{array}$ & $<5$ years & Well & Home & Health worker & 6 & Yes & 6 months & $\begin{array}{l}\text { Reduction, } \\
\text { cessation }\end{array}$ & $A, B, C, E$ \\
\hline $\begin{array}{l}\text { Borrelli } \\
\text { et al } \\
\text { (2016) } \\
{[15]}\end{array}$ & $3-17$ years & $\begin{array}{l}\text { Asthmatic, } \\
\text { Well }\end{array}$ & Home & $\begin{array}{l}\text { Clinical } \\
\text { psychologists }\end{array}$ & $\begin{array}{l}2 \text { educational } \\
\text { home visits, } \\
6 \text { calls after } \\
\text { home visits }\end{array}$ & No & 12 months & Cessation & $A, B, C$ \\
\hline $\begin{array}{l}\text { Chan et al } \\
(2005) \\
{[16]}\end{array}$ & Children & $\begin{array}{l}\text { Hospital/ } \\
\text { clinic visit }\end{array}$ & Hospital & Nurse & 1 & No & 1 month & Cessation & $\mathrm{B}, \mathrm{C}$ \\
\hline $\begin{array}{l}\text { Chan et al } \\
(2016) \\
{[17]}\end{array}$ & $\begin{array}{l}0-18 \\
\text { months }\end{array}$ & Well & Home & Nurse & 5 & Yes & 12 months & $\begin{array}{l}\text { Reduction, } \\
\text { cessation }\end{array}$ & $A, B, C, E$ \\
\hline $\begin{array}{l}\text { Curry } \\
\text { et al } \\
(2003) \\
{[18]}\end{array}$ & Children & $\begin{array}{l}\text { Hospital/ } \\
\text { clinic visit }\end{array}$ & Pediatric & Nurse & 4 & No & 12 months & Cessation & $A, B, C$ \\
\hline $\begin{array}{l}\text { Eriksen } \\
\text { et al } \\
(1996) \\
{[19]}\end{array}$ & $\begin{array}{l}6 \text { weeks, } \\
2 \text { years, } 4 \\
\text { years }\end{array}$ & Well & Pediatric & Clinic Staff & 1 & No & 1 month & $\begin{array}{l}\text { Reduction, } \\
\text { cessation }\end{array}$ & $A, B$ \\
\hline $\begin{array}{l}\text { Green- } \\
\text { berg et al } \\
(1994) \\
{[20]}\end{array}$ & $<6$ months & Well & Home & Nurse & 4 & Yes & 6 months & Reduction & $A, B$ \\
\hline $\begin{array}{l}\text { Hovell } \\
\text { et al } \\
(2002) \\
{[21]}\end{array}$ & $3-17$ years & Asthmatic & Home & $\begin{array}{l}\text { Research } \\
\text { assistant }\end{array}$ & 7 & Yes & 12 months & Reduction & B \\
\hline $\begin{array}{l}\text { Hughes } \\
\text { et al } \\
\text { (1991) } \\
{[22]}\end{array}$ & $6-16$ years & Asthmatic & $\begin{array}{l}\text { Hospital } \\
\text { and } \\
\text { family } \\
\text { home }\end{array}$ & Nurse & 4 & No & 12 months & Reduction & B \\
\hline $\begin{array}{l}\text { Kallio } \\
\text { et al } \\
(2006) \\
{[23]}\end{array}$ & 5 months & Well & $\begin{array}{l}\text { Well-baby } \\
\text { clinic }\end{array}$ & Physician & 16 & No & 8 years & $\begin{array}{l}\text { Reduction, } \\
\text { cessation }\end{array}$ & $A, B$ \\
\hline $\begin{array}{l}\text { Krieger } \\
\text { et al } \\
(2005) \\
{[24]}\end{array}$ & $4-12$ years & Asthmatic & Home & $\begin{array}{l}\text { Research } \\
\text { assistant }\end{array}$ & $5-9$ & No & 12 months & Reduction & B \\
\hline $\begin{array}{l}\text { Schuck } \\
\text { et al } \\
(2014) \\
{[12]}\end{array}$ & $9-12$ years & Well & School & $\begin{array}{l}\text { Quitline staff, } \\
\text { Research } \\
\text { assistant }\end{array}$ & 7 & No & 12 months & Cessation & $A, B, C$ \\
\hline $\begin{array}{l}\text { Severson } \\
\text { et al } \\
\text { (1997) } \\
{[25]}\end{array}$ & $<6$ months & Well & $\begin{array}{l}\text { Hospital } \\
\text { and } \\
\text { well-baby } \\
\text { clinic }\end{array}$ & Physician & 4 & No & 12 months & $\begin{array}{l}\text { Reduction, } \\
\text { cessation }\end{array}$ & $A, B$ \\
\hline
\end{tabular}


Table 1. Characteristics of included studies

\begin{tabular}{|c|c|c|c|c|c|c|c|c|c|}
\hline Study & $\begin{array}{c}\text { Age of } \\
\text { Child at } \\
\text { Recruitment }\end{array}$ & $\begin{array}{l}\text { Child } \\
\text { Cohort }\end{array}$ & Setting & Provider & $\begin{array}{l}\text { No. of } \\
\text { Sessions }\end{array}$ & $\begin{array}{l}\text { Theory } \\
\text { Based }\end{array}$ & $\begin{array}{l}\text { Length of } \\
\text { Observation }\end{array}$ & $\begin{array}{l}\text { Primary } \\
\text { Goal }\end{array}$ & $\begin{array}{l}\text { Intervention } \\
\text { Components }\end{array}$ \\
\hline $\begin{array}{l}\text { Vineis } \\
\text { et al } \\
\text { (1993) } \\
{[26]}\end{array}$ & 0-3 months & Well & $\begin{array}{l}\text { Well-baby } \\
\text { clinic }\end{array}$ & Nurse & NR & No & 2 years & Cessation & $A, B$ \\
\hline $\begin{array}{l}\text { Wahlgren } \\
\text { et al } \\
\text { (1997) } \\
{[27]}\end{array}$ & $6-17$ years & Asthmatic & Pediatric & $\begin{array}{l}\text { Research } \\
\text { assistant }\end{array}$ & 6 & Yes & 2 years & Reduction & $A, B$ \\
\hline $\begin{array}{l}\text { Wilson } \\
\text { et al } \\
(2011) \\
{[28]}\end{array}$ & $3-12$ years & Asthmatic & Home & $\begin{array}{l}\text { Research } \\
\text { assistant }\end{array}$ & 6 & Yes & 12 months & Reduction & $B, C, E$ \\
\hline $\begin{array}{l}\text { Wood- } \\
\text { ward et al } \\
\text { (1987) } \\
{[29]}\end{array}$ & Newborn & Well & Hospital & $\begin{array}{l}\text { Research } \\
\text { assistant }\end{array}$ & 1 & No & 3 months & Reduction & $A, C$ \\
\hline $\begin{array}{l}\text { Yilmaz } \\
\text { et al } \\
(2006) \\
{[30]}\end{array}$ & $<16$ years & Well & Hospital & Nurse & 1 & No & 6 months & $\begin{array}{l}\text { Reduction, } \\
\text { cessation }\end{array}$ & $A, B$ \\
\hline $\begin{array}{l}\text { Zakarian } \\
\text { et al } \\
(2004) \\
{[31]}\end{array}$ & $<4$ years & Well & Home & Clinic staff & 7 & Yes & 12 months & Reduction & $A, B, C$ \\
\hline
\end{tabular}

A, self-help materials; $B$, counseling; $C$, phone support; $D$, medication; $E$, biochemical

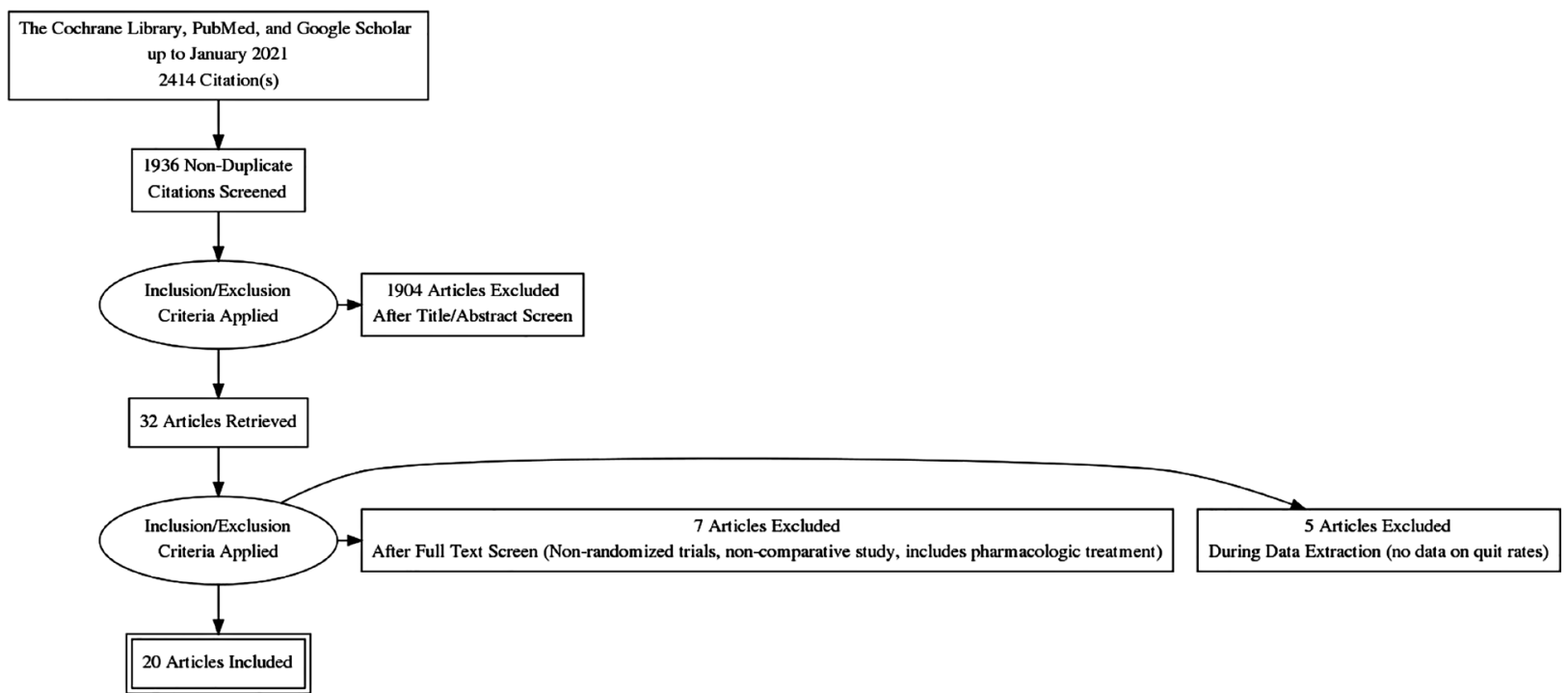

Figure 1. PRISMA flow chart of included studies

$(\mathrm{RR}=1.22,95 \% \mathrm{Cl}=1.01$ to $1.46, p$-value $=0.04)$. The studies demonstrated moderate heterogeneity only $\left(\mathrm{I}^{2}=54 \%\right)$. Figure 3 shows the meta-analysis on quit rate.

To explore heterogeneity, subgroup analyses were conducted in the year of publication. The pooled RR demonstrated that among studies published prior to year 2000, no significant difference was observed between parental smoking cessation program and control $(\mathrm{RR}=1.02,95 \% \mathrm{Cl}=0.62$ to 1.70 , p-value $=0.93)$. The studies demonstrated low heterogeneity $\left(I^{2}=45 \%\right)$. On the other hand, the pooled 


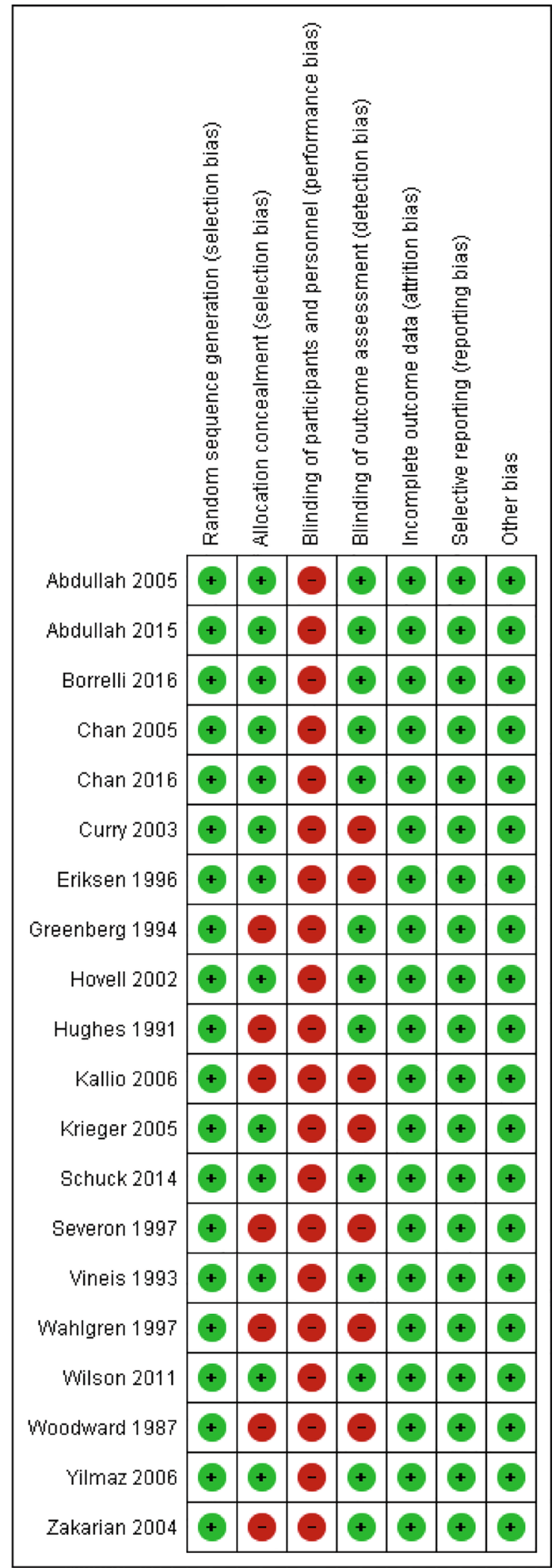

Figure 2. Risk of bias summary of included studies

RR demonstrated that among studies published after 2020, the parental smoking cessation program was significantly associated with higher quit rates $(R R=1.27,95 \% \mathrm{Cl}=1.03$ to 1.56 , $p$-value $<0.0001)$. The studies demonstrated high heterogeneity
$\left(I^{2}=62 \%\right)$. Figure 4 shows the meta-analysis of effect on quit rates with sub-group by year published.

Sub-group analysis was also done on type of intervention. The pooled RR demonstrated that among studies with self-help interventions, the parental smoking cessation program has no additional benefit on quit rates $(R R=1.20,95 \% \mathrm{Cl}=0.94$ to 1.58, p-value $=0.14)$. The studies demonstrated high heterogeneity $\left(I^{2}=64 \%\right)$. Figure 5 shows metaanalysis of the effect on quit rates of studies with self-help interventions.

The pooled RR demonstrated that among studies with biofeedback intervention, no significant difference was observed between the parental smoking cessation program and control (RR $=1.27$, $95 \% \mathrm{Cl}=0.86$ to $1.89, p$-value $=0.23)$. The studies demonstrated low heterogeneity $\left(1^{2}=0 \%\right)$. The meta-analysis regarding biofeedback intervention is shown in Figure 6.

Funnel plot analysis indicated no risk for publication bias (see Figure 7).

\section{DISCUSSION}

Two of the most recent and high-quality studies included in this meta-analysis are described in the succeeding section. A longitudinal randomized trial was conducted to better understand the role of a teachable moment (TM) on the parents' motivation for smoking cessation [15]. The study's aims were as follows: (1) the TM: whether second-hand smoke exposure (SHSe) feedback motivates cessation in parents of children with asthma versus parents of healthy children; and (2) whether greater intervention intensity [enhanced-precaution adoption model (PAM)] is more effective than a previously tested intervention (PAM) in cessation. A TM is any life event or health event that has the potential to motivate behavior change. Included in the study done from 2007 to 2013 was a total of 560 smoking patients (341 were parents of children with asthma; 219 were parents of healthy children). The intervention that the participants obtained were two 1-hour educational home visits and smoking cessation induction counseling, nicotine patches if medically eligible and ready to quit within 30 days, and six 15-minute calls for 4 months after the home visits. After the second home visit, asthma participants were randomized to get either PAM or enhanced PAM. Primary outcome measures were 7-day point 


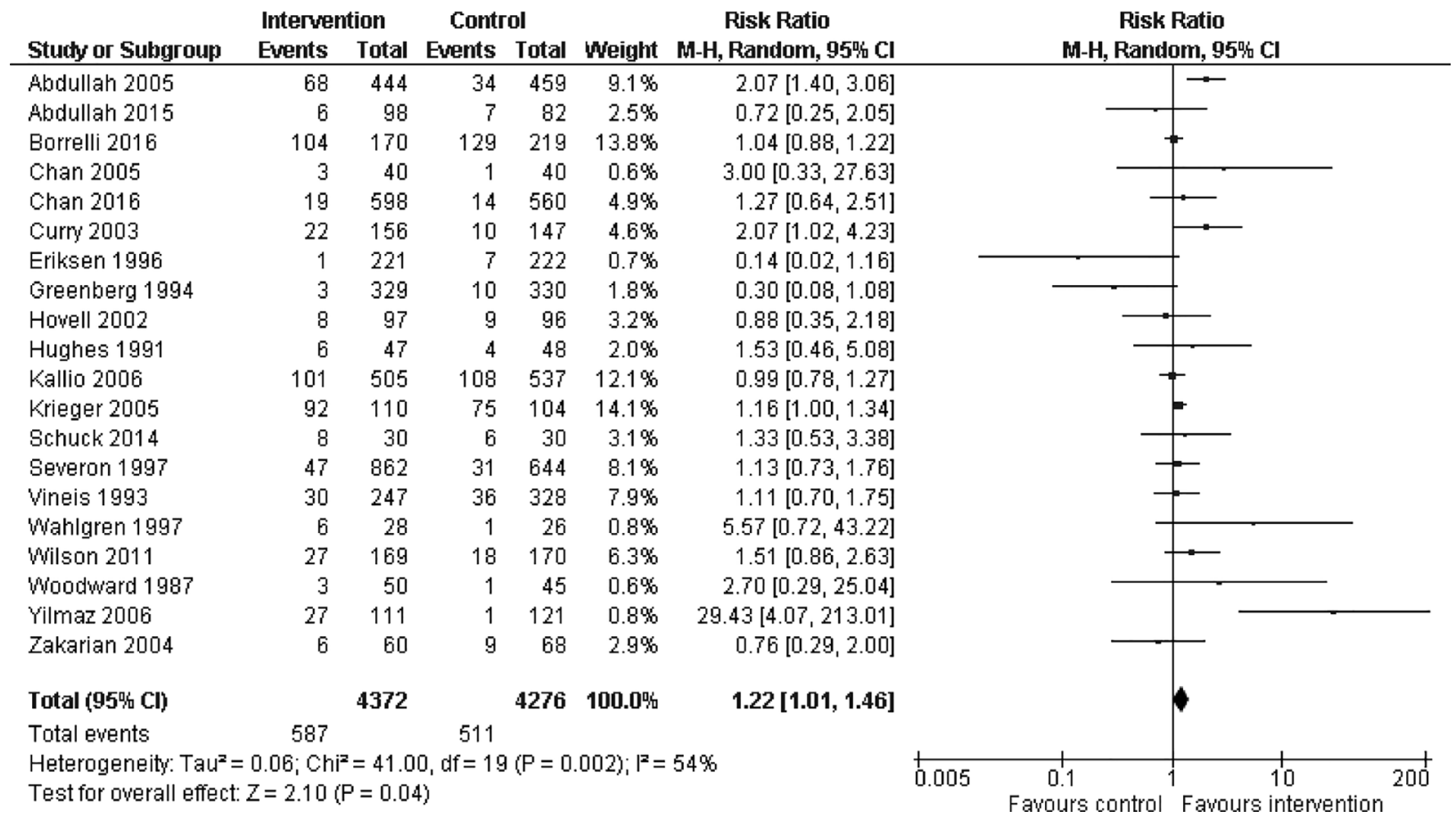

Figure 3. Meta-analysis of effect on quit rates

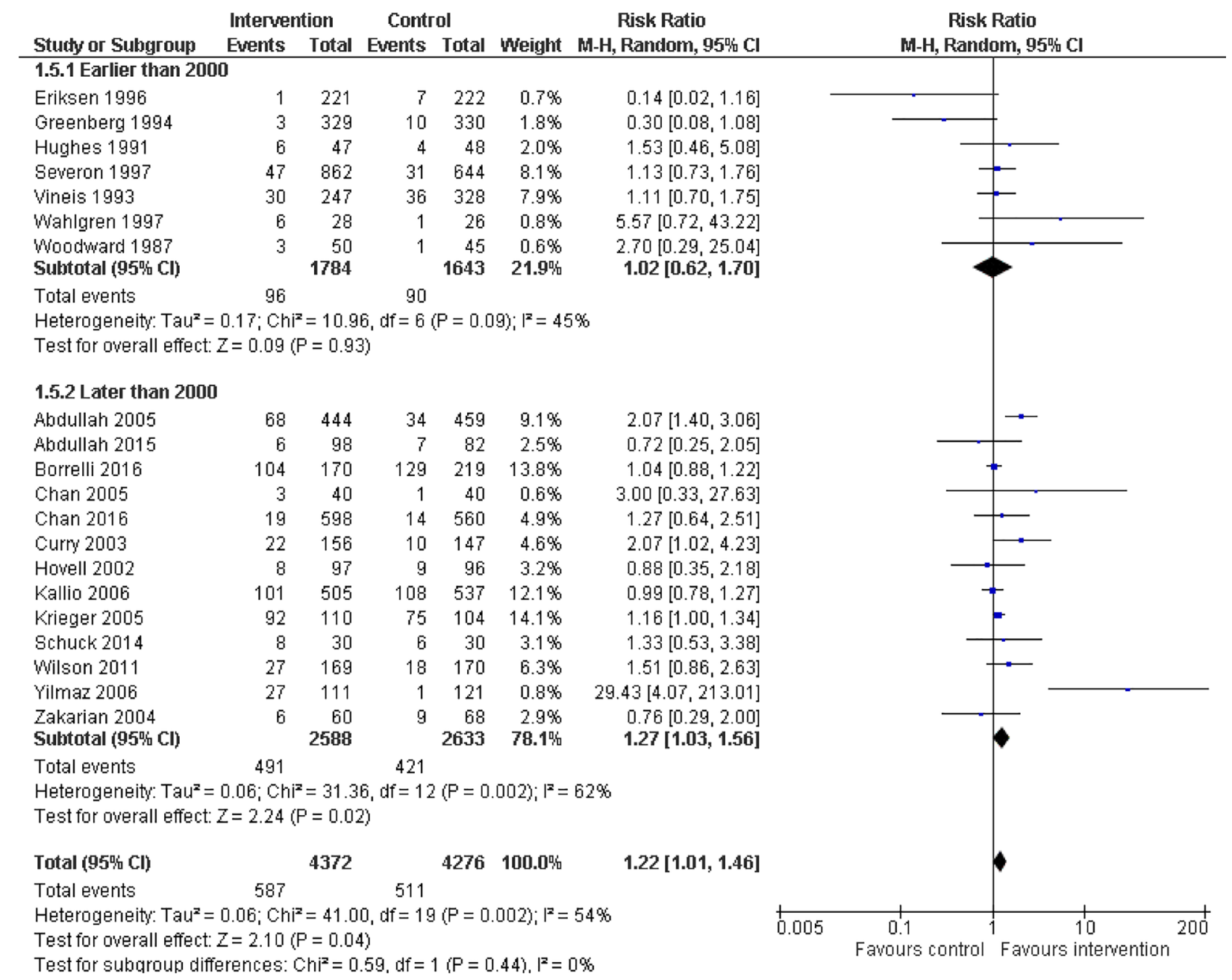

Figure 4. Meta-analysis of effect on quit rates with sub-group by year published 


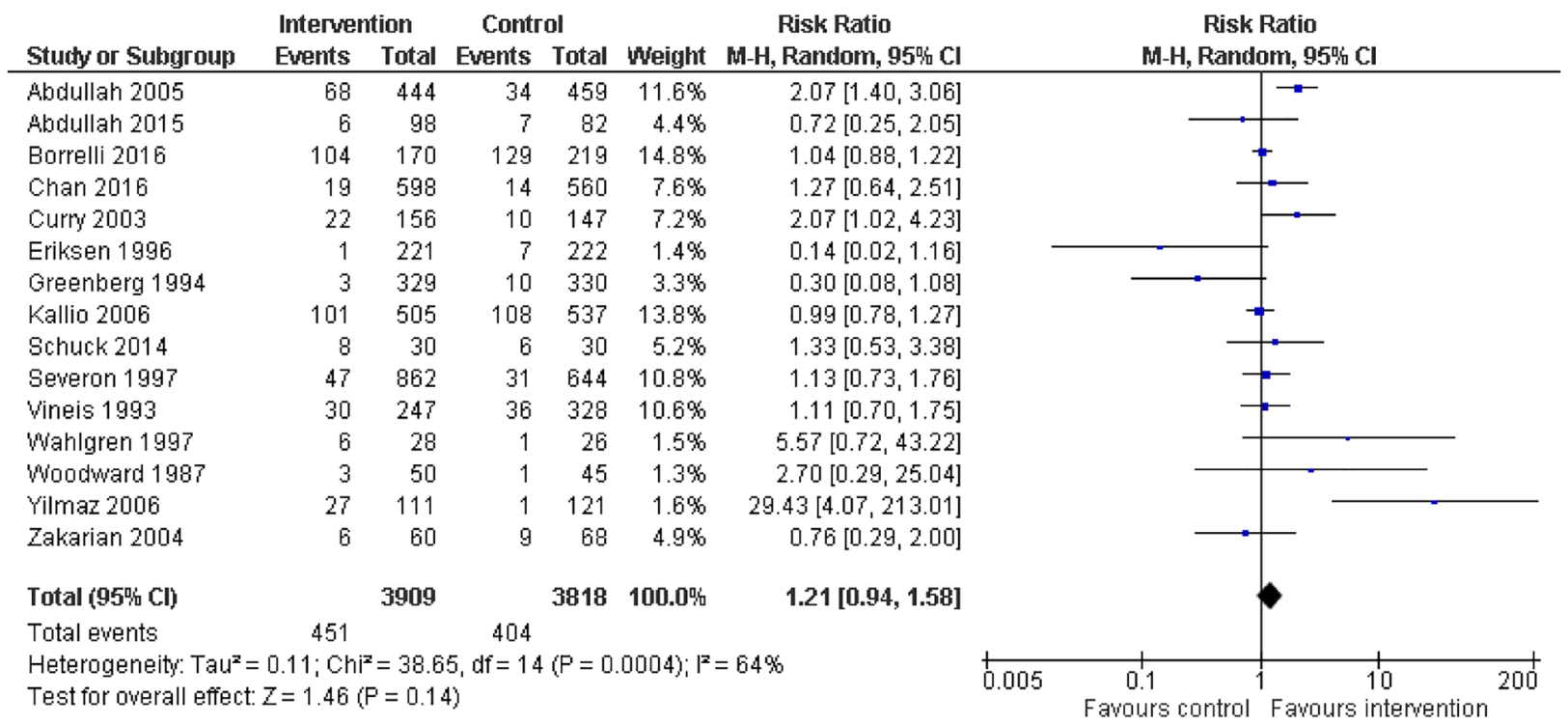

Figure 5. Meta-analysis of effect on quit rates of studies with self-help interventions

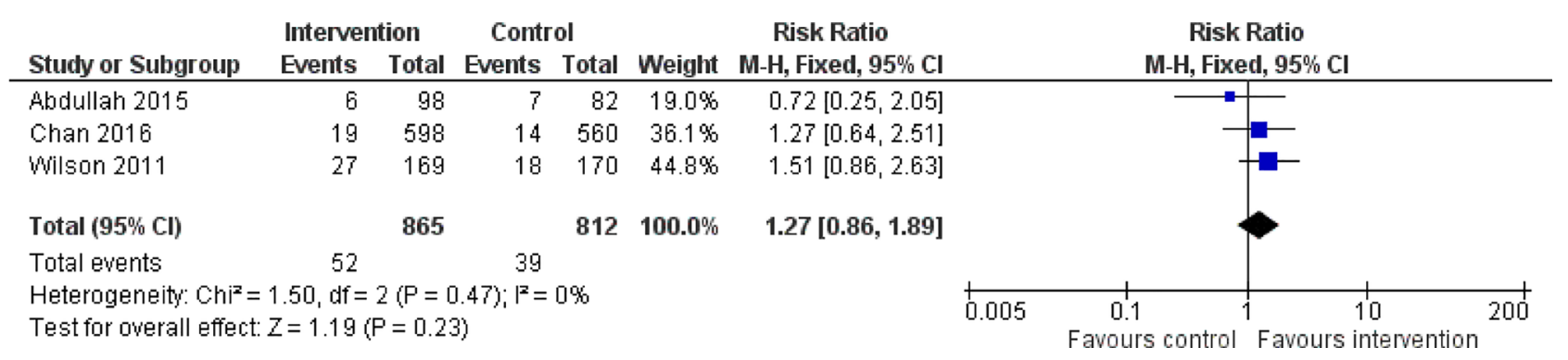

Figure 6. Meta-analysis of effect on quit rates of studies with biofeedback

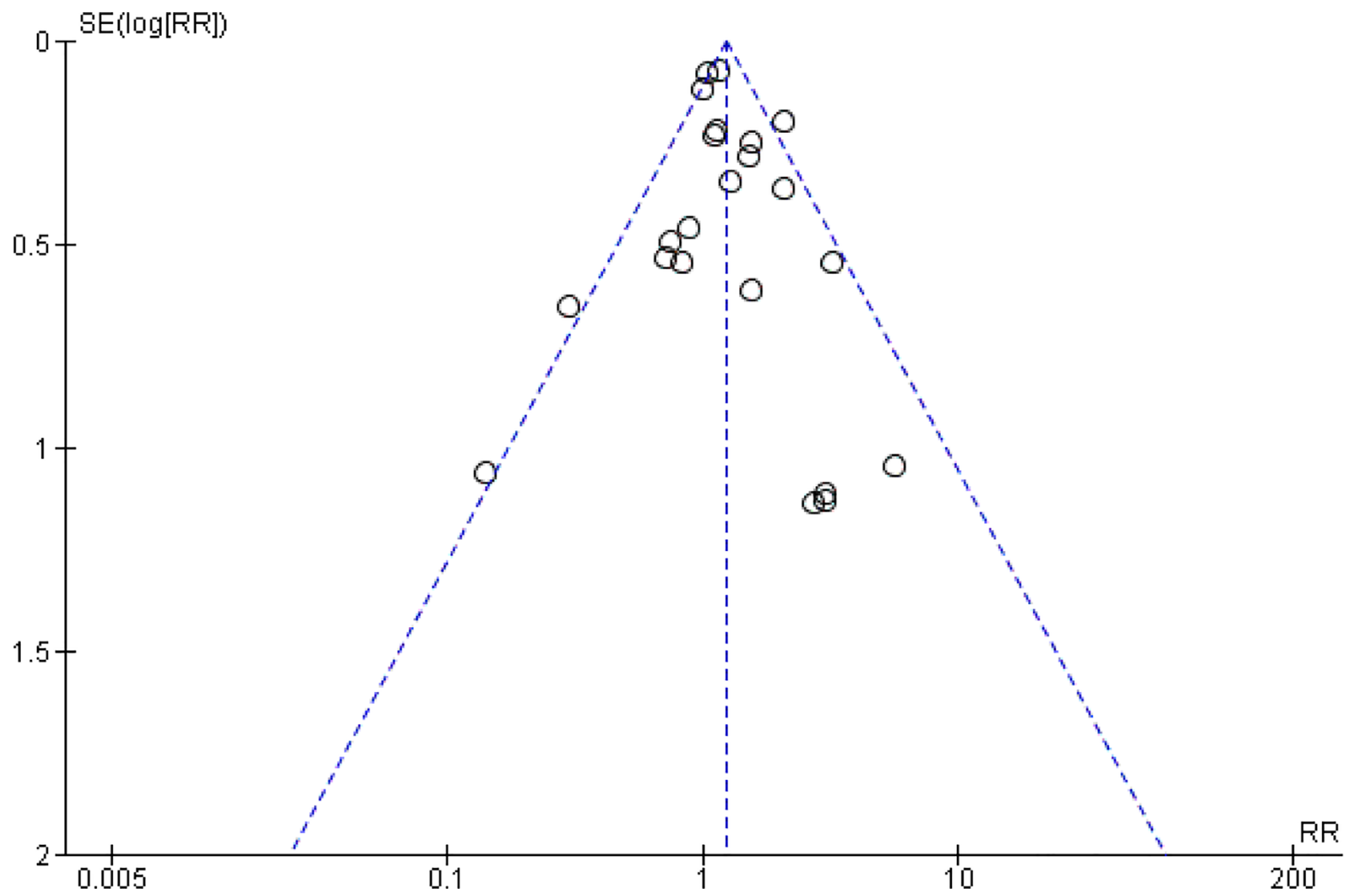

Figure 7. Funnel plot analysis on risk for publication bias 
prevalence abstinence (PPA) and 30-day PPA. To quantify $\mathrm{SHSe}$, two passive nicotine monitors were placed for 1 week during baseline and after call number 5 , with one monitor in the room where the child spends most of his time and another monitor worn by the child. Secondary outcome measures include a number of asthma-related hospitalizations, school days missed due to asthma, days with asthma symptoms, and Asthma Functional Morbidity Scale score. Program satisfaction was also assessed. Also, for every questionnaire completed by participants at the following different time points (baseline, 2, 4, 6, and 12 months) $\$ 20$ were given.

Among the 560 participants, 40\% were not ready to quit, $18 \%$ never tried to quit, $46 \%$ lived with another smoker, and $55 \%$ had a household smoking ban. There was no significant difference found on motivational interviewing indicators Iglobal spirit, empathy, reflection to question ratio, percentage open-ended questions, and percentage adherent) when audio tapes from home visits were analyzed. Results of this study have shown evidence that providing an intervention after a TM motivates parental smoking cessation and decreases SHSe. Parents randomized to PAM were more than twice as likely to produce 7-day and 30-day PPA versus the same treatment provided to the parents of healthy children. Furthermore, stronger effects were found among parents randomized to enhanced PAM. These results also gave evidence to suggest that secondhand exposure feedback was motivated by $T M$, which resulted in increased cessation rates. It is to be noted that between PAM and enhanced PAM, no significant differences in terms of cessation rates, even after receiving the extra feedback, were observed. Moreover, the effect of the feedback was not sustained beyond the four months.[15]

The authors cited the following limitations of the study. There was the presence of some components that might not be feasible for routine clinical care (feedback on SHSe) that were included. Furthermore, due to the short half-life of 4 to 6 hours for carbon monoxide, the 7-day and 30-day PPA cannot be verified. The authors in the study were able to conclude that the use of motivational interviewing for smoking cessation, included during asthma education, was able to increase smoking cessation rates. Also, the enhanced PAM model used was effective in reducing $\mathrm{SHSe}$ and increased asthma care utilization.[15]
Another randomized clinical trial was performed to examine a family-based intervention in a Chinese context. [17] The objective of the study was to test the long-term efficacy of a family-based intervention, which includes nurse-led individual telephone counseling for the smoking father and nonsmoking mother and a family counseling session (FCS) discussing SHSe of their child and the father's smoking cessation. Non-smoking mothers were selected at recruitment sites, which are maternal and child health centers $(\mathrm{MCHs})$ in Hong Kong. The mothers were randomized to two groups: the intervention group received an onsite counseling session, telephone counseling sessions, 2 self-help booklets on smoking cessation, follow-up sessions from the nurse counselor, and participated in the FCS; and the control group received a 2-page leaflet on the importance of establishing a smokefree home, self-help smoking cessation pamphlet for the fathers, and brief advice. The primary outcome measure was father-reported PPA in the past 7 days and at 6 months follow-up. Secondary outcome measures included biochemically validated abstinence, self-reported abstinence for at least 24 hours, reduction in daily cigarette consumption, and infant's saliva cotinine concentrations at the 6-and 12-month follow-ups.

Results have shown that a higher number of fathers in the intervention group had a 7-day PPA compared to the control group at both 6-month and 12-month follow-ups. There was also an observed significant group difference in the fathers' reported smoking reduction by at least $50 \% \quad 30.6 \%$ vs $24.1 \%)$ and quit attempts $(22.0 \%$ vs $15.8 \%)$, but not fathers' abstinence as reported by the mothers $(14.9 \%$ vs $12.1 \%)$. Group counseling via FCS was also effective, as fathers who participated in the FCS had higher 7-day PP quit rates at 12-month follow-up compared to the control group. In addition, mothers who participated in the FCS were more likely to help motivate the fathers, which in turn resulted in higher psychosocial support rates. Infant saliva cotinine levels showed no significant difference between groups at 6 -month $(1.01 \mathrm{ng} / \mathrm{ml}$ vs $0.86 \mathrm{ng} / \mathrm{ml})$ and 12 -month follow-ups $(0.81 \mathrm{ng} / \mathrm{ml}$ vs $0.80 \mathrm{ng} / \mathrm{ml}$ ). This shows that SHSe was not significant between the intervention and control groups.[17]

Limitations to the study include a high attrition rate, bias due to free nicotine replacement therapy (NRT) and cash incentive, substantial changes in 
tobacco control policies, and low participation rate in biochemical validation of the father's abstinence.[17]

The authors concluded that the nurse-led familybased smoking cessation intervention was effective as it increased the father's long-term self-reported abstinence. Providing assistance to both smoking fathers and nonsmoking mothers is beneficial to protect their children from SHSe. In addition, the FCS attended by the couple further increased quit rates and the mothers' help and support to the fathers. [17]

Overall, this meta-analysis provided support in the use of non-pharmacologic interventions for parental smoking cessation. Using the GRADE quality of evidence, the results showed a moderate quality of evidence due to modest effect size (RR $=1.21$, $95 \% \mathrm{Cl}=1.09$ to 1.33 ) and moderate heterogeneity $\left(1^{2}=54 \%\right)$. Heterogeneity decreased in magnitude after sub-group analysis. Strengths of this study that supports confidence in the results include large overall sample size, large number of studies, and high methodologic quality of included studies. The current meta-analysis is also consistent with that conducted by Rosen, et al. [8], which observed modest effect size in favor of parental smoking cessation programs $(R R=1.34,95 \% \mathrm{Cl}=1.05$ to 1.71$)$. Their study had 18 trials but also included pharmacologic treatment. The current meta-analysis is unique as it focused on non-pharmacologic treatment only and conducted sub-group analysis in terms of year of publication and different intervention components. It was found out in the subgroup analysis that selfhelp interventions and biofeedback monitoring are not enough to be effective, thereby calling the need for additional counseling interventions. Interestingly, studies published earlier than 2000 showed no significant benefit of parental smoking cessation programs. This shows that the intervention on counseling for smoking cessation may have evolved in terms of concepts and methodology to be more effective in recent years. Future studies may look at other factors which may affect quit rates in parental smoking cessation programs to further improve the effectiveness of this intervention.

\section{CONCLUSION AND RECOMMENDATION}

This meta-analysis demonstrated sufficient evidence that non-pharmacologic interventions for parental smoking cessation are effective. Counseling intervention in addition to self-help interventions or biofeedback to prevent SHSe among children of smokers are highly recommended to facilitate quitting or abstinence. Further studies are recommended to evaluate the sustainability of parental smoking cessation programs and whether these interventions offer long-term benefits even after the interventions have ended.

\section{CONFLICT OF INTEREST STATEMENT}

All authors (Drs. Stefanie Nichole Tan, Jose Caduhada, Ma. Teresa Tricia Bautista) declare that the research was done with no conflicts of interest to disclose.

\section{Acknowledgments}

The authors would like to express their deepest gratitude to Mr. Raymark Salonga and Mrs. Czariane Bugarin-Salonga for their extended support in the preparation of this study. 


\section{REFERENCES}

1. World Health Organization. 2020. Available from: https:// www.who.int/news/item/08-12-2020-who-launches-yearlong-campaign-to-help-100-million-people-quit-tobacco

2. Centers for Disease Control and Prevention. 2020. Available from: https://www.cdc.gov/tobacco/data_statistics/fact_ sheets/fast_facts/index.htm\#: : :text=Cigarette\%20smoking $\% 20$ is $\% 20$ responsible\%20for,or\%201\%2C300\%20 deaths $\% 20$ every $\% 20$ day. \&text=On\%20average $\% 2$ C $\% 20$ smokers $\% 20$ die $\% 2010 \% 20$ years $\% 20$ earlier $\% 20$ than $\% 20$ nonsmokers.

3. Legg T. 2017. Available from: https://www.healthline. $\mathrm{com} /$ health/copd/smoking-relapse\#: : text=The $\% 20$ most $\% 20$ common $\% 20$ causes $\% 20$ of,you $\% 20$ decide $\% 20$ to $\% 20$ quit\%20smoking.

4. World Health Organization. WHO Report on the Global Tobacco Epidemic, 2019. Geneva: World Health Organization, 2019 [cited 2021 Jan 26].

5. Brewer NT, Chapman GB, Gibbons FX, Gerrard M, McCaul KD, Weinstein ND. Meta-analysis of the relationship between risk perception and health behavior: the example of vaccination._Health Psychol. 2007;26(2):136-45.

6. Hubbard G, Gorely T, Ozakinci G, Polson R, Forbat L. A systematic review and narrative summary of family-based smoking cessation interventions to help adults quit smoking. BMC Family Practice. 2016;17(1):1-20.

7. Priest N, Roseby R, Waters E, Polnay A, Campbell R, Spencer $N$, et al. Family and carer smoking control programmes for reducing children's exposure to environmental tobacco smoke. Cochrane Database Syst Rev [Internet]. 2008;(4):CD001746. Available from: http://dx.doi. org/10.1002/14651858.CD001746.pub2

8. Rosen L, Noach MB, Winickoff JP, Hovell MF. Parental smoking cessation to protect young children: a systematic review and meta-analysis. Pediatrics. 2012;129(1):14152. doi:10.1542/peds.2010-3209

9. Caldwell AL, Tingen MS, Nguyen JT, Andrews JO, Heath J, Waller JL, et al. Parental smoking cessation: Impacting children's tobacco smoke exposure in the home. Pediatrics. 2018;141(Supplement 1):S96-106.

10. Bricker J, Leroux BG, Peterson AV, Kealey KA, Sarason IG, Andersen $M R$, et al. Nine-year prospective relationship between parental smoking cessation and children's daily smoking. Addiction. 2003;98(5):585-93.

11. Chassin L, Presson C, Rose J, Sherman SJ, Prost J. Parental smoking cessation and adolescent smoking. Journal of Pediatric Psychology. 2002;27(6):485-96.

12. Schuck K, Bricker JB, Otten R, Kleinjan M, Brandon $T H$, Engels RC. Effectiveness of proactive quitline counselling for smoking parents recruited through primary schools: results of a randomized controlled trial. Addiction. 2014;109(5):830-41.

13. Abdullah AS, Hua F, Khan H, Xia X, Bing Q, Tarang $K$, et al. Secondhand smoke exposure reduction intervention in Chinese households of young children: a randomized controlled trial. Academic Pediatrics. 2015;15(6):588-98.

14. Abdullah ASM, Mak YW, Loke AY, Lam TH. Smoking cessation intervention in parents of young children: a randomised controlled trial. Addiction. 2005;100(1 1):1731-40.

15. Borrelli B, McQuaid EL, Tooley EM, Busch AM, Hammond SK, Becker B, et al. Motivating parents of kids with asthma to quit smoking: the effect of the teachable moment and increasing intervention intensity using a longitudinal randomized trial design. Addiction. 2016;1 11 (9):1646-55.

16. Chan SSC, Lam TH, Salili F, Leung GM, Wong DCN, Botelho RJ, et al. A randomized controlled trial of an individualized motivational intervention on smoking cessation for parents of sick children: a pilot study. Appl Nurs Res [Internet]. 2005; 18(3):178-81. Available from: http://dx.doi. org/10.1016/i.apnr.2005.01.002

17. Chan SSC, Cheung YTD, Fong DYT, Emmons K, Leung AYM, Leung DYP, et al. Family-based smoking cessation intervention for smoking fathers and nonsmoking mothers with a child: a randomized controlled trial [published correction appears in J Pediatr. 2017 Jun; 185:255]. J Pediatr. 2017;182:260-266.e4. doi:10.1016/i. jpeds.2016.11.021

18. Curry SJ, Ludman EJ, Graham E, Stout J, Grothaus L, Lozano P. Pediatric-based smoking cessation intervention for lowincome women: a randomized trial. Arch Pediatr Adolesc Med. 2003;157(3):295-302.

19. Eriksen W, Sørum K, Bruusgaard D. Effects of information on smoking behaviour in families with preschool children. Acta Paediatr [Internet]. 1996;85(2):209-12. Available from: http://dx.doi.org/10.1111/j.1651-2227.1996. tb 13994.x

20. Greenberg RA, Strecher VJ, Bauman KE, Boat BW, Fowler MG, Keyes LL, et al. Evaluation of a home-based intervention program to reduce infant passive smoking and lower respiratory illness. Journal of Behavioral Medicine. 1994;17(3):273-90.

21. Hovell MF, Meltzer SB, Wahlgren DR, Matt GE, Hofstetter $C R$, Jones JA, et al. Asthma management and environmental tobacco smoke exposure reduction in Latino children: a controlled trial. Pediatrics [Internet]. 2002;110(5):94656. Available from: http://dx.doi.org/10.1542/ peds. 110.5 .946

22. Hughes DM, McLeod M, Garner B, Goldbloom RB. Controlled trial of a home and ambulatory program for asthmatic children. Pediatrics. 1991;87(1):54-61.

23. Kallio $K$, Jokinen $E$, Hämäläinen $M$, Kaitosaari $T$, Volanen I, Viikari J, et al. Impact of repeated lifestyle counselling in an atherosclerosis prevention trial on parental smoking and children's exposure to tobacco smoke. Acta Paediatr [Internet]. 2006;95(3):283-90. Available from: http://dx.doi. org/10.1080/08035250500375145

24. Krieger JW, Takaro TK, Song L, Weaver M. The Seattle-King County Healthy Homes Project: a randomized, controlled trial of a community health worker intervention to decrease exposure to indoor asthma triggers. Am J Public Health [Internet]. 2005;95(4):652-9. Available from: http:// dx.doi.org/10.2105/AJPH.2004.042994

25. Severson HH, Andrews JA, Lichtenstein E, Wall M, Akers $L$. Reducing maternal smoking and relapse: long-term evaluation of a pediatric intervention. Prev Med. 1997;26 (1):120-30

26. Vineis P, Ronco G, Ciccone G, Vernero E, Troia B, D'Incalci $\mathrm{T}$, et al. Prevention of exposure of young children to parental tobacco smoke: effectiveness of an educational program. Tumori [Internet]. 1993;79(3):183-6. Available from: http://dx.doi.org/10.1177/030089169307900304.

27. Wahlgren DR, Hovell MF, Meltzer SB, Hofstetter CR, Zakarian JM. Reduction of environmental tobacco smoke exposure in asthmatic children. A 2-year follow-up. Chest [Internet]. 1997;111(1):81-8. Available from: http:// dx.doi.org/10.1378/chest. 111.1 .81 
28. Wilson S, Farber H, Knowles S, Lavori P. A randomized trial of parental behavioral counseling and cotinine feedback for lowering environmental tobacco smoke exposure in children with asthma: results of the LET'S Manage Asthma trial. Chest. 2011;139(3):581-90.

29. Woodward A, Owen N, Grgurinovich N, Griffith F, Linke $\mathrm{H}$. Trial of an intervention to reduce passive smoking in infancy. Pediatric Pulmonology. 1987;3(3):173-8.

30. Yilmaz G, Karacan C, Yöney A, Yilmaz T. Briefintervention on maternal smoking: a randomized controlled trial. Child Care Health Dev [Internet]. 2006;32(1):73-9. Available from: http://dx.doi.org/10.1111/j.1365-2214.2006.00570.x

31. Zakarian JM, Hovell MF, Sandweiss RD, Hofstetter CR, Matt GE, Bernert JT, et al. Behavioral counseling for reducing children's ETS exposure: implementation in community clinics. Nicotine Tob Res [Internet]. 2004;6(6):1061-74. Available from: http://dx.doi. org/10.1080/1462220412331324820 (c) (i) (2) Open Access This article is licensed under a (c) ${ }_{\text {BY NC SA }}$ Creative Commons Attribution-NonCommercialShareAlike 4.0 International License, which permits use, share - copy and redistribute the material in any medium or format, adapt - remix, transform, and build upon the material, as long as you give appropriate credit, provide a link to the license, and indicate if changes were made. You may do so in any reasonable manner, but not in any way that suggests the licensor endorses you or your use. You may not use the material for commercial purposes. If you remix, transform, or build upon the material, you must distribute your contributions under the same license as the original. You may not apply legal terms or technological measures that legally restrict others from doing anything the license permits. The images or other third party material in this article are included in the article's Creative Commons license, unless indicated otherwise in a credit line to the material. If material is not included in the article's Creative Commons license and your intended use is not permitted by statutory regulation or exceeds the permitted use, you will need to obtain permission directly from the copyright holder. To view a copy of this license, visit https://creativecommons.org/licenses/by-nc-sa/4.0/. 